\title{
PENERAPAN KONSEP OMNIBUS LAW PADA PENGATURAN KEWENANGAN PENEGAKAN HUKUM DI LAUT ${ }^{1}$
}

\author{
Dhiana Puspitawati \\ Fakultas Hukum Universitas Brawijaya \\ Jalan MT. Haryono No.169 Malang \\ dhiana@ub.ac.id
}

\begin{abstract}
The concept of Omnibus Law, which is considered as solution to overlapping regulations, will be also applied in the aspect of law enforcement at sea. This paper seeks to analyze whether such concept is suitable to be applied in the aspect of law enforcement at sea. This research uses normative method with regulation approach. It is argued that the application of omnibus law concept on the law enforcement at sea, is unsuitable. This is because UNCLOS 1982 provides various maritime zones with the recognition of other states' rights over such maritime zones. Thus, it is submitted that relevant regulations should be revised and harmonized.
\end{abstract}

Keywords: Law Enforcement; Omnibus Law; Marine Governance; Coast Guard; Bakamla

\begin{abstract}
Abstrak
Konsep omnibus law yang dianggap dapat menjadi solusi pada permasalahan yang timbul akibat adanya pengaturan yang tumpang tindih, juga akan diterapkan pada tata kelola laut khususnya di bidang penegakan hukum di laut. Artikel ini akan menganalisis apakah penerapan konsep omnibus law tepat bila dilakukan pada aspek penegakan hukum di laut. Metode yang digunakan dalam artikel ini adalah yuridis normatif dengan pendekatan perundang-undangan. Meskipun terdapat tumpang tindih pengaturan dalam penegakan hukum di laut, penerapan konsep omnibus law dalam hal penegakan hukum tidaklah tepat. Hal ini dikarenakan adanya pengaturan UNCLOS 1982 tentang zona maritim yang mengakui hak-hak negara lain di wilayah laut, baik wilayah laut yang merupakan kedaulatan negara pantai maupun wilayah yurisdiksi negara pantai. Diperlukan harmonisasi dan revisi peraturan perundang-undangan terkait penegakan hukum di laut.
\end{abstract}

Kata Kunci: Penegakan Hukum; Omnibus Law; Tata Kelola Laut; Coast Guard; Bakamla

\footnotetext{
${ }^{1}$ Artikel hasil Penelitian DPP/SPP Fakultas Hukum Universitas Brawijaya T.A. 2020, Sumber Dana: Fakultas Hukum Universitas Brawijaya, tahun 2020.
} 


\section{A. Pendahuluan}

Perkembangan hukum di Indonesia saat ini sedang mengarah kepada penerapan konsepsi omnibus law yang masih dituangkan dalam bentuk Rancangan Undang-Undang, yang dikenal dengan RUU Cipta Kerja (yang saat ini sudah disahkan menjadi Undang-Undang). Hal ini dikarenakan konsepsi omnibus law dianggap bisa memberikan solusi terhadap berbagai tumpang tindih peraturan perundangundangan yang ada di Indonesia. Secara harfiah omnibus sendiri diartikan sebagai 'untuk semua' atau 'untuk segalanya', sedangkan omnibus law diartikan sebagai 'hukum untuk semua.' Secara singkat omnibus law dapat diartikan sebagai suatu undang-undang yang dibentuk dalam rangka mencabut, mengubah, merevisi dan menggabungkan beberapa peraturan perundang-undangan yang dianggap saling tumpang tindih dan disharmoni menjadi satu undang-undang yang memayungi beberapa undang-undang terkait. Adapun keuntungan dari omnibus law di antaranya adalah lebih efektif dan efisien dikarenakan pemerintah tidak perlu merevisi atau mencabut undangundang secara satu persatu. Di samping itu penerapan omnibus law dapat meniadakan ego sektoral di suatu bidang yang sama dan dengan demikian dianggap lebih menjamin kepastian hukum. Pada awalnya, penerapan konsep omnibus law yang masih dituangkan dalam bentuk RUU Omnibus Law di Indonesia ditujukan pada tiga aspek yang meliputi perpajakan, cipta lapangan kerja dan UMKM. Hal ini tidak lain adalah untuk mendorong pertumbuhan perekonomian di Indonesia dengan memangkas birokrasi yang panjang serta tumpang tindih. Pada perkembangannya, konsepsi omnibus law ini direkomendasikan untuk diterapkan di berbagai aspek yang belum tentu sesuai dengan akar permasalahan yang ada.

Aspek kelautan terutama dalam hal penegakan hukum di laut tak luput dari siraman konsepsi omnibus law ini. Pada saat ini ada setidaknya lebih dari 10 instansi yang mempunyai kewenangan dalam penegakan hukum di laut (TNI AL, 2014). Kondisi inilah yang kemudian menjadikan adanya tumpang tindih ketentuan penegakan hukum di laut dan tidak efektifnya proses penegakan hukum di laut. Secara tradisional, baik hukum internasional maupun hukum nasional mengakui kewenangan TNI-AL sebagai penegak hukum di laut (TNI AL, 2014). Adapun kewenangan penegakan hukum yang dimiliki oleh TNI-AL juga termasuk kewenangan sebagai penyidik di laut (Undang-Undang Nomor 34 Tahun 2004 tentang Tentara Nasional Indonesia). Kewenangan tersebut tidak dibatasi dengan pengaturan zona maritim yang ditentukan oleh UNCLOS 1982. Dengan kata lain TNIAL mempunyai kewenangan penegakan hukum di semua zona maritim mulai dari perairan pedalaman sampai dengan laut bebas. Secara nasional, di samping TNI-AL, Indonesia juga mempunyai unsur penegak hukum yang disebut Badan Keamanan Laut (Bakamla) serta Penjaga Laut dan Pantai atau yang disebut dengan Sea and Coast Guard serta beberapa instansi lain.

Artikel ini di samping akan membahas kewenangan TNI-AL, juga akan menganalisis kewenangan Bakamla dan Kesatuan Penjaga Laut dan Pantai (KPLP) dikarenakan kedua institusi ini menyebut dirinya sebagai coast guard, padahal sea and coast guard yang diamanatkan oleh Pasal 276 Undang-Undang Nomor 17 Tahun 2008 tentang Pelayaran (UU Pelayaran) belum pernah dibentuk. Alhasil Badan Keamanan Laut (Bakamla) menyuarakan bahwa dengan penerapan konsep omnibus law maka Bakamla menjadi penegak hukum tunggal di laut ("Omnibus Law Kelautan, Bakamla Penegak Hukum Tunggal di Laut," 2020). Dari pernyataan tersebut ada beberapa hal yang harus digarisbawahi, yaitu: (1) apa sebenarnya yang dimaksud dengan coast guard dan apa perbedaannya dengan Bakamla?; (2) Bagaimana pengaturan penegakan hukum di laut, selain yang dilakukan oleh TNI-AL? Apakah Indonesia sudah mempunyai coast guard serta apa dasar hukum pendirian coast guard? Lalu apa sebenarnya tugas dan fungsi masingmasing Bakamla dan sea and coast guard; 
dan (3) bagaimana pengaturan penegakan hukum di laut ke depan? Artikel ini akan menganalisis apakah penerapan konsep omnibus law tepat bila dilakukan pada tata kelola laut, khususnya pada aspek penegakan hukum di laut.

\section{B. Metode Penelitian}

Penelitian ini merupakan jenis penelitian yuridis normatif dengan pendekatan statute dan comparative approach, yaitu penggunaan isi dari peraturan hukum untuk mengkaji permasalahan atau insiden yang pernah terjadi dalam kaitannya dengan pelaksanaan penegakan hukum di perairan Indonesia. Adapun sumber bahan hukum primer yang digunakan mencakup: Undang-Undang Nomor 17 Tahun 1985 tentang Ratifikasi UNCLOS 1982; Undang-Undang Nomor 6 Tahun 1996 tentang Perairan Indonesia; Undang-Undang Nomor 3 Tahun 2002 tentang Pertahanan Negara; Undang-Undang Nomor 34 Tahun 2004 tentang Tentara Nasional Indonesia; Undang-Undang Nomor 17 Tahun 2008 tentang Pelayaran; UndangUndang Nomor 32 Tahun 2014 tentang Kelautan; Peraturan Presiden Nomor 178 Tahun 2014 tentang Bakamla.

Bahan hukum sekunder dalam penelitian ini, meliputi praktek stakeholder tentang penegakan hukum di laut, prinsipprinsip hukum laut internasional, pendapat para ahli serta artikel-artikel Ilmiah yang berkaitan dengan fokus tulisan ini. Selanjutnya, bahan hukum tersier meliputi Black Law Dictionary, Kamus Besar Bahasa Indonesia serta Encyclopedia of International Law.

\section{Hasil dan Pembahasan}

\section{Konsep Omnibus Law: Bakamla sebagai Penegak Hukum Tunggal di Laut}

Omnibus law berasal dari bahasa latin yang artinya 'untuk semua' atau 'banyak', secara harfiah dapat didefinisikan sebagai hukum untuk semua. Omnibus law dapat diartikan sebagai regulasi atau Undang-
Undang yang mencakup berbagai isu atau topik. Menurut Bryan A Garner, dalam Black Law dictionary menyebutkan bahwa "omnibus relating to or dealing with numerous objects or items at once, including many things or having various purposes." (Garner, 2009). Artinya bahwa dengan omnibus law suatu undang-undang dapat mengatur berbagai obyek sekaligus dan memiliki berbagai tujuan. Konsep ini bertujuan untuk menghasilkan suatu regulasi yang bersifat menyeluruh dan komprehensif serta tidak terikat pada satu rezim pengaturan saja. Omnibus law ini mulai diterapkan di Indonesia pada era pemerintahan Presiden Joko Widodo. Adapun tujuan penerapan tersebut adalah untuk memperbaiki tingkat perekonomian Indonesia. Sehingga yang disasar oleh omnibus law meliputi 3 sektor yaitu perpajakan, cipta lapangan kerja dan usaha mikro, kecil dan menengah atau yang biasa disebut sebagai UMKM.

Berbicara penegakan hukum di laut tentunya tidak sesederhana penegakan hukum di darat. Hal ini disebabkan di laut diakui berbagai zona-zona maritim sebagaimana diatur dalam Hukum Internasional yaitu Konvensi Hukum Laut 1982 (KHL 1982), dimana Indonesia sudah meratifikasi Konvensi ini dan konsekuensinya harus tunduk pada semua ketentuan-ketentuan yang ada di KHL 1982 tersebut (Agoes, 1991). Pada zona-zona maritim tersebut, kewenangan negara pantai dan negara pengguna sangat bervariasi tergantung pada rejim hukum yang berlaku pada zona maritim tersebut (Churchill \& Lowe, 1999; Purvis, 2011). Pada prinsipnya semakin jauh wilayah laut tersebut dari daratan (dari garis pangkal kepulauan) maka semakin berkurang pula kewenangan negara pantai (Puspitawati, 2018). Hal ini disebabkan karena di wilayah laut tersebut sudah ada hak negara lain dan sudah diakui oleh masyarakat internasional. Misalnya, pada wilayah ZEE, Indonesia tidak mempunyai kedaulatan lagi akan tetapi hanya mempunyai hak berdaulat. Hak berdaulat adalah hak eksklusif negara pantai 
dalam hal tertentu saja. Dalam hal ZEE, negara pantai hanya mempunyai hak eksklusif di bidang eksplorasi dan eksploitasi sumber daya alam (Harahap, 2017). UNCLOS 1982 selanjutnya juga memberikan keleluasaan pada negara pantai untuk memberlakukan ketentuan hukumnya sesuai dengan kewenangan yang diberikan oleh konvensi pada masing-masing zona maritim. Meskipun demikian UNCLOS 1982 tetap mewajibkan negara pantai untuk tetap memperhatikan ketentuan-ketentuan lainnya yang relevan yang ada dalam UNCLOS 1982

Selanjutnya berbeda dengan penegakan hukum di darat, penegakan hukum di laut harus memperhatikan ketentuan-ketentuan Hukum Internasional yang berlaku dan hakhak negara lain yang diakui di wilayah laut tersebut. Memang saat ini ada setidaknya lebih dari 10 instansi yang mempunyai kewenangan dalam penegakan hukum di laut (TNI AL, 2014). Kondisi inilah yang kemudian menjadikan adanya tumpang tindih ketentuan penegakan hukum di laut dan tidak efektifnya proses penegakan hukum di laut. Akan tetapi bukan berarti penerapan konsep Omnibus Law menjadi solusinya. Secara tradisional, baik hukum internasional maupun hukum nasional mengakui kewenangan TNI-AL sebagai penegak hukum di laut (TNI AL, 2014). Adapun kewenangan penegakan hukum yang dimiliki oleh TNI-AL juga termasuk kewenangan sebagai penyidik di laut (Undang-Undang Nomor 34 Tahun 2004 tentang Tentara Nasional Indonesia). Kewenangan tersebut tidak dibatasi dengan pengaturan zona maritim yang ditentukan oleh UNCLOS 1982. Dengan kata lain TNIAL mempunyai kewenangan penegakan hukum di semua zona maritim mulai dari perairan pedalaman sampai dengan laut bebas. Meskipun Pasal 9 Undang-Undang Nomor 34 Tahun 2004 tentang Tentara Nasional Indonesia menyebutkan bahwa kewenangan TNI-AL hanya di wilayah yurisdiksi Indonesia, akan tetapi Pasal 1 undang-undang yang sama menyebutkan bahwa TNI-AL sebagai salah satu unsur keamanan negara juga bertugas menegakkan kedaulatan di wilayah kedaulatan Indonesia, dalam hal ini meliputi perairan pedalaman, perairan kepulauan dan laut territorial.

Secara nasional, di samping TNI-AL, Indonesia juga mempunyai unsur penegak hukum yang disebut Badan Keamanan Laut (Bakamla) serta Penjaga Laut dan Pantai atau yang disebut dengan Sea and Coast Guard serta beberapa instansi lain. Selain pada TNI-AL, artikel ini hanya akan fokus pada Bakamla dan Kesatuan Penjaga Laut dan Pantai (KPLP) dikarenakan kedua institusi ini menyebut dirinya sebagai coast guard, padahal sea and coast guard yang diamanatkan oleh Pasal 276 UndangUndang Nomor 17 Tahun 2008 tentang Pelayaran (UU Pelayaran) belum pernah dibentuk. Pembentukan Bakamla merupakan amanat dari Pasal 59 ayat (3) UndangUndang Nomor 32 Tahun 2014 tentang Kelautan (UU Kelautan); sedangkan pembentukan Sea and Coast Guard merupakan amanat Bab XVII Pasal 276 Undang-Undang Nomor 17 Tahun 2008 tentang Pelayaran (UU Pelayaran). Adapun Pasal 59 ayat (3) UU kelautan berbunyi:

"Dalam rangka penegakan hukum di wilayah perairan dan wilayah yurisdiksi, khususnya dalam melaksanakan patrol keamanan dan keselamatan di wilayah perairan dan wilayah yurisdiksi Indonesia, dibentuk Badan Keamanan Laut.”

Sedangkan Pasal 276 ayat (1) dan (2) UU Pelayaran berbunyi:

"(1) Untuk menjamin terselenggaranya keselamatan dan keamanan di laut dilaksanakan fungsi penjagaan dan penegakan peraturan perundangundangan di laut dan pantai

(2) Pelaksanaan fungsi sebagaimana dimaksud pada ayat (1) dilakukan oleh penjaga laut dan pantai." (penebalan oleh peneliti)

Selanjutnya Pasal 1 ayat (59) UU pelayaran menyebutkan bahwa:

"Penjagaan laut dan pantai (sea and coast guard) adalah lembaga yang 
melaksanakan fungsi penjagaan dan penegakan peraturan perundangundangan di laut dan pantai yang dibentuk dan bertanggung jawab kepada Presiden dan secara teknis operasional dilaksanakan oleh Menteri."

Sayangnya UU Pelayaran tidak mendefinisikan apa yang dimaksud dengan 'laut' dan 'pantai', sedangkan Pasal 1 ayat (2) hanya mendefinisikan perairan Indonesia sebagai laut territorial Indonesia beserta perairan kepulauan dan perairan pedalaman. Meskipun demikian, dari pengaturan Pasal 1 ayat (1) sebenarnya jelas bahwa UU Pelayaran hanya berlaku di wilayah perairan Indonesia saja, yaitu sampai batas terluar laut territorial dan tidak termasuk di wilayah yurisdiksi Indonesia (Mahmud, 2017). Sedangkan dari ketentuan Pasal 59 UU Kelautan jelas disebutkan bahwa kewenangan pengamanan yang dilakukuan oleh Bakamla meliputi wilayah perairan dan wilayah yurisdiksi Indonesia. Dengan demikian terjadi tumpang tindih antara kewenangan Bakamla dan KPLP di wilayah perairan Indonesia atau di sampai batas terluar laut territorial. Pengaturan demikian menyebabkan adanya tumpang tindih norma (overlappig norms) antara kedua undangundang tersebut, sehingga diupayakan penerapan konsep omnibus law di sektor kelautan, khususnya dalam hal penegakan hukum di laut. Hasil sementara dari upaya penerapan omnibus law dalam penegakan hukum di laut memunculkan ide bahwa Bakamla akan menjadi penegak hukum tunggal di laut.

Sebagai negara peratifikasi UNCLOS 1982 melalui Undang-Undang Nomor 17 Tahun 1985 tentang ratifikasi UNCLOS 1982, ketentuan hukum nasional tentang pengelolaan dan pemanfaatan laut harus disesuaikan dengan ketentuan-ketentuan yang ada dalam UNCLOS 1982 (Dupuy \& Vignes, 1991; Emmers, 2010; Feldt, Roell, \& Thiele, 2013). UNCLOS 1982 mengatur bahwa semakin jauh suatu wilayah laut dari pantai, maka semakin kecil pula kewenangan negara pantai di wilayah laut tersebut. Hal ini disebabkan karena di wilayah laut tersebut sudah ada hak negara lain dan sudah diakui oleh masyarakat internasional. Misalnya, pada wilayah ZEE, Indonesia tidak mempunyai kedaulatan lagi akan tetapi hanya mempunyai hak berdaulat. UNCLOS 1982 selanjutnya juga memberikan keleluasaan pada negara pantai untuk memberlakukan ketentuan hukumnya sesuai dengan kewenangan yang diberikan oleh konvensi pada masing-masing zona maritim (Suwardi, 2017). Meskipun demikian UNCLOS 1982 tetap mewajibkan negara pantai untuk tetap memperhatikan ketentuan-ketentuan lainnya yang relevan yang ada dalam UNCLOS 1982. Keleluasaan tersebut termasuk dalam pengaturan penegakan hukum. Dalam hal penegakan hukum, UNCLOS 1982 hanya mengenal state ships dan warship sebagai entitas yang berwenang dalam penegakan hukum (Agoes, 1991; Muchjiddin, 1993). Alhasil, selain kapal perang, Indonesia mempunyai berbagai state ships dari berbagai institusi negara. Dengan setidaknya 10 institusi yang berwenang dalam penegakan hukum di laut, seharusnya keamanan di laut, khususnya di perairan Indonesia semakin terjamin. Sayangnya, angka pelanggaran di laut tidak semakin menurun, bahkan perairan Indonesia dikenal sebagai perairan yang rawan, baik karena bencana maupun karena ancaman terhadap keamanan dan keselamatan pelayaran (Kadar, 2015). Pernyataan Presiden Joko Widodo, pada pelantikan $\mathrm{Ka}$ Bakamla tanggal 12 Februari 2020 mengatakan bahwa ke depan Bakamla akan menjadi embrio coast guard Indonesia dan dengan demikian institusi lainnya akan dikembalikan pada tugas dan fungsi masing-masing institusi (BeritaSatu, 2020), menjadi titik tolak tentang pembahasan apa sebenarnya yang dimaksud dengan coast guard.

\section{Pengaturan Coast Guard dan Bakamla}

\section{a. Pengertian Coast Guard}

Belum ada kesepakatan secara universal tentang pengertian coast 
guard. Fungsi coast guard bahkan berbeda-beda untuk setiap negara. Akan tetapi secara umum dalam praktek negara-negara, coast guard mempunyai fungsi yang meliputi (Nursal, 2020): 1) Search and Rescue; 2) Penegakan Hukum di Laut; 3) Penjagaan Keselamatan Navigasi; 4) Perlindungan Lingkungan Laut; dan 5) Penjagaan Keamanan Perbatasan. Secara harfiah mungkin coast guard dapat diterjemahkan sebagai penjaga pantai. Sehingga menimbulkan intepretasi bahwa coast guard yang dimaksud oleh UU Pelayaran adalah KPLP. Akan tetapi nomenklatur 'laut' pada KPLP juga membingungkan karena tidak jelas juga laut bagian mana yang akan dijaga. Guna memberikan gambaran tentang tugas dan fungsi coast guard dalam praktek negara-negara maka akan dilakukan identifikasi tugas dan fungsi coast guard di negara lain. Meskipun belum ada pengertian universal tentang apa yang dimaksud dengan coast guard, akan tetapi pada umumnya coast guard merupakan komponen cadangan keamanan di laut suatu negara. Di Amerika coast guard merupakan institusi otonom yang memiliki alutsita sendiri serta berwenang dalam hal penegakan hukum dan fungsi polisionil. Di Inggris, coast guard hanya bersifat administratif dan tidak mempunyai alutsita sendiri. Di Perancis, coast guard memadukan coast guard model Amerika dan Inggris. Sedangkan di Pakistan berfungsi sebagai Maritime Security Agency yang merupakan komponen pendukung di laut. Guna mempermudah pemahaman di bawah ini akan diuraikan perbandingan praktek negara-negara tentang coast guard dalam bentuk tabel.

Tabel 1.

Perbandingan Fungsi Coast Guard di Negara-Negara

\begin{tabular}{|c|c|c|c|}
\hline US Coast Guard & British Coast Guard & French Coast Guard & Pakistan Coast Guard \\
\hline 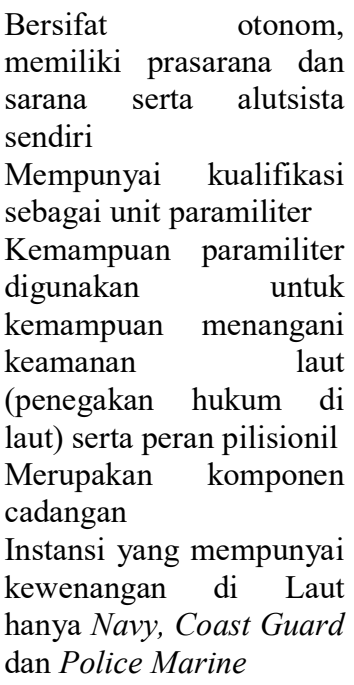 & $\begin{array}{l}\text { Hanya } \\
\text { administratif, } \\
\text { memiliki alutsista sendiri } \\
\text { Hanya bertindak sebagai } \\
\text { koordinator dan } \\
\text { penghubung } \\
\text { Kesuksesan coast guard } \\
\text { ditentukan oleh koordinasi } \\
\text { yang baik ditunjang } \\
\text { komitmen nasional yang } \\
\text { tinggi terhadap bidang } \\
\text { tugas dan kemanusiaan } \\
\text { serta partisipasi } \\
\text { masyarakat dan organisasi } \\
\text { non-pemerintah }\end{array}$ & $\begin{array}{l}\text { Merupakan perpaduan } \\
\text { antara coast guard model } \\
\text { Amerika dan Inggris } \\
\text { Bersifat otonom dan } \\
\text { memiliki alutsista sendiri } \\
\text { Tidak mempunyai } \\
\text { kewenangan pada } \\
\text { penegakan hukum } \\
\text { Bukan unit paramiliter/ } \\
\text { komponen cadangan }\end{array}$ & $\begin{array}{l}\text { Merupakan Maritime } \\
\text { Security Agency } \\
\text { Memiliki tanggungjawab } \\
\text { atas perlindungan wilayah } \\
\text { laut sampai ZEE } \\
\text { Memiliki kewenangan } \\
\text { penegakan hukum } \\
\text { Sebagai komponen } \\
\text { pendukung kekuatan di } \\
\text { laut dalam situasi darurat }\end{array}$ \\
\hline
\end{tabular}


Dengan demikian, yang perlu dicermati dalam coast guard dan institusi penegak hukum di laut yang lainnya pembedaan ada area operasinya masing-masing. Di samping itu juga harus dijelaskan tugas, fungsi dan kewenangan masing-masing institusi yang mempunyai kewenangan penegakan hukum di laut. Eksistensi coast guard mungkin bisa menjadi solusi bagi tumpang tindihnya kewenangan penegak hukum di laut. Akan tetapi perlu digarisbawahi bahwa eksistensi coast guard tidak menghilangkan eksistensi TNI-AL dikarenakan TNI-AL mempunyai 3 peran yang meliputi military, constabulary dan diplomacy yang tidak dapat digantikan oleh institusi lain atau biasa dikenal dengan Trisila TNI-AL. Hal ini sesuai dengan peran universal Angkatan laut sebagaimana diutarakan oleh Ken Booth (Booth, 1985; Pranoto \& Amrulla, 2015; Ruolngul, n.d.) dalam diagram di bawah ini:

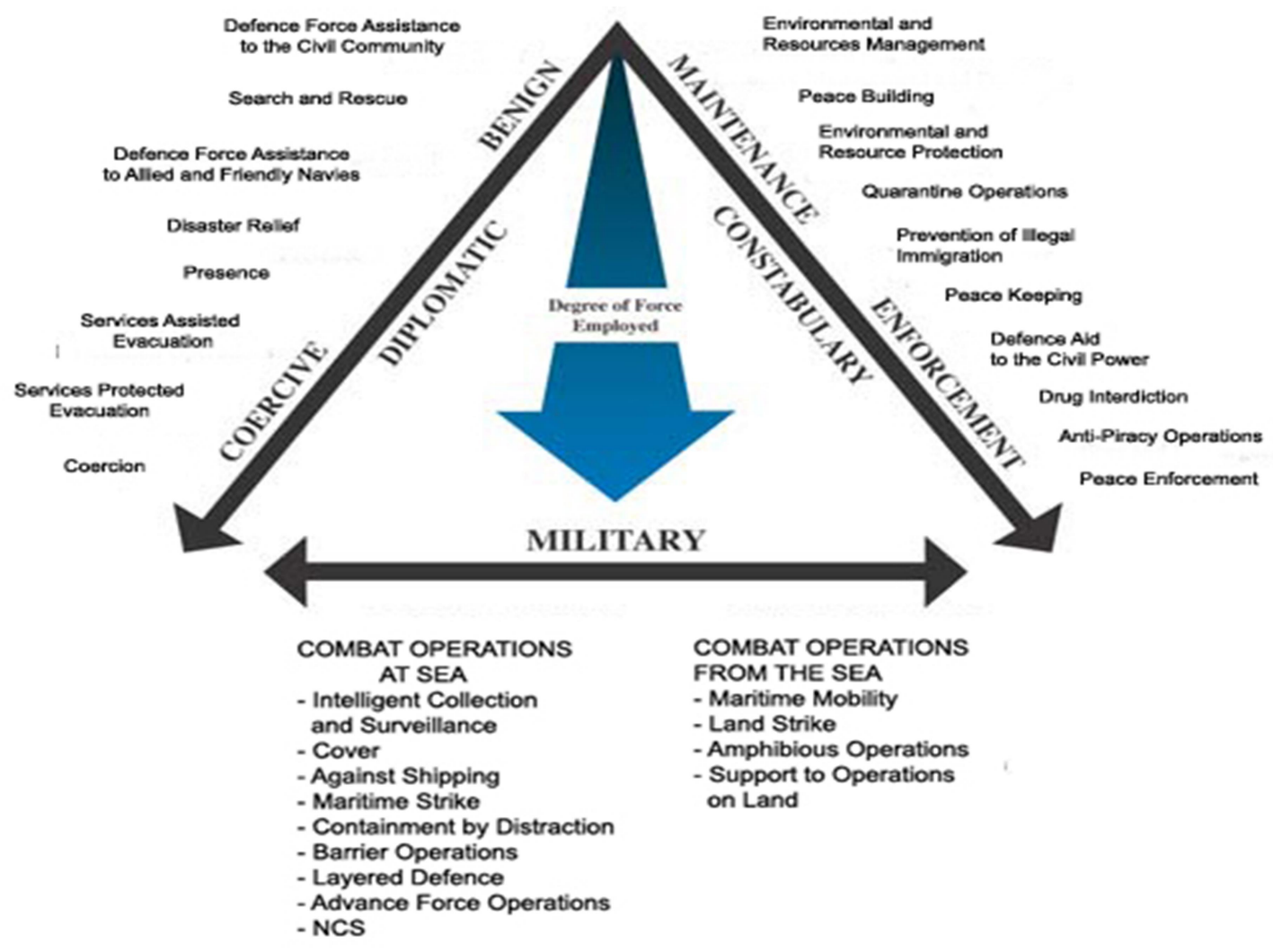

Gambar 1.

Peran Universal Angkatan Laut 
Dengan demikian, jika omnibus law diaplikasikan pada bidang penegakan hukum di laut, maka tidak akan menghilangkan eksistensi TNI-AL, dikarenakan adanya Trisila TNI-AL tersebut.

\section{b. Dasar Hukum Bakamla dan Sea and Coast Guard: Tugas, Fungsi dan Kewenangan}

Nomenklatur 'sea and coast guard' dalam peraturan perundang-undangan Indonesia dapat ditemukan dalam Pasal 276 Undang-Undang Nomor 17 Tahun 2008 tentang Pelayaran (UU Pelayaran), yang mengatur sebagai berikut:

(1) Untuk menjamin terselenggaranya keselamatan dan keamanan di laut dilaksanakan fungsi penjagaan dan penegakan peraturan perundangundangan di laut dan pantai

(2) Pelaksanaan fungsi sebagaimana dimaksud pada ayat (1) dilakukan oleh penjaga laut dan pantai

(3) Penjaga laut dan pantai sebagaimana dimaksud pada ayat (2) dibentuk dan bertanggungjawab kepada Presiden dan secara teknis operasional dilaksanakan oleh Menteri.

Selanjutnya, Pasal 281 undangundang yang sama menyatakan bahwa pembentukan penjaga laut dan pantai sebagaimana diatur dalam pasal 276 akan diatur lebih lanjut oleh Peraturan Pemerintah. Sayangnya sampai laporan penelitian ini ditulis, belum dikeluarkan suatu Peraturan Pemerintah yang mendirikan 'sea and coast guard' sebagaimana dimaksud pasal 276 tersebut. Akan tetapi, dalam kenyataannya, ada dua institusi yang saat ini menyebut dirinya sebagai 'coast guard' yaitu Bakamla dan Kesatuan Penjaga Laut dan Pantai (KPLP) (Ramadhan, 2020, n. Forum Group Discussion tentang Kewenangan Bakamla dan Sea and Coast Guard dalam Penegakan Hukum di Perairan
Indonesia, tanggal 25 Juli 2020, baik Bakamla maupun KPLP menyebut dirinya sebagai 'coast guard'). Oleh karena itu, dalam bab ini akan dibahas pengaturan kewenangan antara Bakamla, KPLP serta 'sea and coast guard' yang dikehendaki oleh Pasal 276 UU Pelayaran.

Pasal 277 ayat (1) UU Pelayaran mengatur tugas sea and coast guard meliputi: (i) melakukan pengawasan keselamatan dan keamanan pelayaran; (ii) melakukan pengawasan, pencegahan, dan penanggulangan pencemaran di laut; (iii) pengawasan dan penertiban kegiatan serta lalu lintas kapal, (iv) pengawasan dan penertiban kegiatan salvage, pekerjaan bawah air, serta eksplorasi dan eksploitasi kekayaan laut; (v) pengamanan Sarana Bantu Navigasi-Pelayaran; dan (vi) mendukung pelaksanaan kegiatan pencarian dan pertolongan jiwa di laut (Pasal 277 Ayat (1) Undang Undang Nomor 17 Tahun 2008 tentang Pelayaran, Lembaran Negara Republik Indonesia Tahun 2008 Nomor 64, Tambahan Lembaran Negara Republik Indonesia Nomor 5603, 2008) Sedangkan Pasal 277 ayat (2) menyebutkan bahwa sea and coast guard juga mempunyai tugas untuk berkoordinasi dalam kaitannya dengan perumusan kebijakan serta mekanisme penegakan hukum di laut (Pasal 277 Ayat (2) Undang Undang Nomor 17 Tahun 2008 tentang Pelayaran, Lembaran Negara Republik Indonesia Tahun 2008 Nomor 64, Tambahan Lembaran Negara Republik Indonesia Nomor 5603, 2008). Sehingga dengan demikian 'sea and coast guard' yang dimaksud oleh Pasal 276 UU Pelayaran ini lebih luas tugasnya daripada Bakorkamla (institusi yang sekarang berubah nama menjadi Bakamla). Pasal 276 ayat (2) UU Pelayaran lebih lanjut mengatur bahwa fungsi 'sea and coast guard' adalah menjamin terselenggaranya keselamatan dan 
keamanan di laut dilaksanakan fungsi penjagaan dan penegakan peraturan perundang-undangan di laut dan pantai. Suatu hal yang menarik adalah bahwa Pasal 278 UU Pelayaran mengatur kewenangan 'sea and coast guard' termasuk pada kewenangan penyidikan, yang tidak dimiliki oleh Bakamla dalam Undang-Undang Nomor 32 Tahun 2014 tentang Kelautan (UU Kelautan) (Undang-Undang Nomor 32 Tahun 2014 Tentang Kelautan Lembaran Negara Republik Indonesia Tahun 2014 Nomor 294, Tambahan Lembaran Negara Republik Indonesia Nomor 5603, 2014). Secara detail Pasal 278 UU Pelayaran mengatur sebagai berikut:

(1) Dalam melaksanakan tugas sebagaimana dimaksud dalam Pasal 277, penjaga laut dan pantai mempunyai kewenangan untuk:

a. Melaksanakan patrol laut;

b. Melakukan pengejaran seketika (hot-pursuit);

c. Memberhentikan dan memeriksa kapal di laut; dan

d. Melakukan penyidikan

(2) Dalam melaksanakan kewenangan sebagaimana dimaksud pada ayat (1) huruf d penjaga laut dan pantai melaksanakan tugas sebagai Penyidik Pegawai Negeri Sipil sesuai dengan ketentuan peraturan perundang-undangan.

(3) Ketentuan lebih lanjut mengenai kewenangan penjaga laut dan pantai diatur dengan Peraturan Pemerintah.

Sebagaimana disebutkan sebelumnya, hingga saat ini belum dikeluarkan Peraturan Pemerintah yang membentuk 'sea and coast guard' sebagaimana diamanatkan oleh Pasal 279 UU Pelayaran. Selanjutnya, akan dianalisa tugas, fungsi dan kewenangan dua institusi yang selama ini menyebut dirinya sebagai coast guard, yaitu Bakamla dan KPLP.
Bakamla yang merupakan alih rupa dari Bakorkamla, diatur dalam UU Kelautan yang juga berfungsi sebagai dasar pembentukan Bakamla. Sebagaimana diatur dalam Pasal 59 ayat (3) UU Kelautan bahwa "[d]alam rangka penegakan hukum di wilayah perairan dan wilayah yurisdiksi, khususnya dalam melaksanakan patroli keamanan dan keselamatan di wilayah perairan dan wilayah yurisdiksi Indonesia, dibentuk Badan Keamanan Laut."(Pasal 59 ayat (3) UndangUndang Nomor 32 Tahun 2014 tentang Kelautan Lembaran Negara Republik Indonesia Tahun 2014 Nomor 294, Tambahan Lembaran Negara Republik Indonesia Nomor 5603, 2014). Adapun Pasal 61 undang-undang yang sama menyebutkan bahwa tugas Bakamla meliputi patroli keamanan dan keselamatan di wilayah perairan Indonesia dan wilayah yurisdiksi Indonesia (Aziz, L, \& Hardiwinoto, 2016).

Selanjutnya fungsi Bakamla sebagaimana diatur dalam Pasal 62 UU kelautan (Pasal 62 Undang-Undang Nomor 32 Tahun 2014 tentang Kelautan Lembaran Negara Republik Indonesia Tahun 2014 Nomor 294, Tambahan Lembaran Negara Republik Indonesia Nomor 5603, 2014) meliputi: (i) menyusun kebijakan nasional di bidang keamanan dan keselamatan di wilayah perairan Indonesia dan wilayah yurisdiksi Indonesia; (ii) menyelenggarakan sistem peringatan dini keamanan dan keselamatan di wilayah perairan Indonesia dan wilayah yurisdiksi Indonesia; (iii) melaksanakan penjagaan, pengawasan, pencegahan, dan penindakan pelanggaran hukum di wilayah perairan Indonesia dan wilayah yurisdiksi Indonesia; (iv) menyinergikan dan memonitor pelaksanaan patroli perairan oleh instansi terkait; (v) memberikan dukungan teknis dan operasional kepada instansi terkait; (vi) memberikan 
bantuan pencarian dan pertolongan di wilayah perairan Indonesia dan wilayah yurisdiksi Indonesia; dan (vii) melaksanakan tugas lain dalam sistem pertahanan nasional. Sedangkan kewenangan Bakamla sesuai dengan Pasal 63 ayat (1) UU Kelautan meliputi: (i) melakukan pengejaran seketika; (ii) memberhentikan, memeriksa, menangkap, membawa, dan menyerahkan kapal ke instansi terkait yang berwenang untuk pelaksanaan proses hukum lebih lanjut; dan (iii) mengintegrasikan sistem informasi keamanan dan keselamatan di wilayah perairan Indonesia dan wilayah yurisdiksi Indonesia. Dari uraian di atas, terlihat bahwa tugas, fungsi dan kewenangan antara 'sea and coast guard' yang diamanatkan oleh Pasal 276 UU Pelayaran saling tumpang tindih dengan tugas, fungsi dan kewenangan Bakamla yang diatur dalam UU Kelautan. Dalam beberapa hal bahkan 'sea and coast guard' mempunyai kewenangan yang lebih luas daripada Bakamla. Dengan demikian perlu dipertanyakan pernyataan Presiden Joko Widodo bahwa Bakamla adalah Indonesian Coast Guard, yang mana sesungguhnya kewenangan Bakamla tidaklah seluar 'sea and coast guard' terutama dalam fungsi 'sea and coast guard' sebagai penyidik, yang mana hal ini tidak termasuk kewenangan Bakamla dalam UU Kelautan. Ditambah lagi bahwa Pasal 62 UU Kelautan juga menyebutkan bahwa fungsi Bakamla juga termasuk tugas lain dalam pertahanan nasional. Lalu bagaimana dengan eksistensi TNI-AL? Apakah tidak tumpang tindih dengan fungsi TNI-AL?

Sesuai dengan Pasal 6 UndangUndang Nomor 32 Tahun 2004 tentang Tentara Nasional Indonesia (UU TNI) (Undang-Undang Nomor 32 Tahun 2004 Tentang Tentara Nasional Indonesia, Lembaran Negara Republik
Indonesia Tahun 2004 Monor 127, Tambahan Lembaran Negara Republik Indonesia Nomor 4439, 2004), fungsi Tentara Nasional Indonesia (TNI) meliputi: (i) penangkal terhadap setiap bentuk ancaman militer dan ancaman bersenjata dari luar dan dalam negeri terhadap kedaulatan, keutuhan wilayah, dan keselamatan bangsa; (ii) penindak terhadap setiap bentuk ancaman sebagaimana dimaksud pada ayat (1) huruf a; dan (iii) pemulih terhadap kondisi keamanan negara yang terganggu akibat kekacauan keamanan. (Pasal 6 Undang-Undang Nomor 32 Tahun 2004 Tentang Tentara Nasional Indonesia, Lembaran Negara Republik Indonesia Tahun 2004 Monor 127, Tambahan Lembaran Negara Republik Indonesia Nomor 4439, 2004). Sedangkan Pasal 9 undang-undang yang sama secara spesifik menyebutkan tugas TNI-AL meliputi: melaksanakan tugas TNI matra laut di bidang pertahanan; menegakkan hukum dan menjaga keamanan di wilayah yurisdiksi nasional sesuai dengan ketentuan hukum nasional dan hukum internasional yang telah diratifikasi; melaksanakan tugas diplomasi Angkatan Laut dalam rangka mendukung kebijakan politik luar negeri yang ditetapkan oleh pemerintah; melaksanakan tugas TNI dalam pembangunan dan pengembangan kekuatan matra laut; serta melaksanakan pemberdayaan wilayah pertahanan laut. Dari Pasal 9 huruf b dapat diketahui bahwa area operasi TNI-AL adalah di wilayah yurisdiksi nasional dan sesuai dengan Pasal 1 ayat (4) UndangUndang Nomor 43 Tahun 2008 tentang Wilayah Negara dengan jelas disebutkan bahwa:

"Wilayah yurisdiksi adalah wilayah di luar wilayah negara yang terdiri atas ZEE, Landas Kontinen dan Zona Tambahan dimana negara memiliki hak-hak berdaulatan dan kewenangan tertentu lainnya 
sebagaimana diatur dalam peraturan perundang-undangan dan hukum internasional."

Selanjutnya kewenangan TNI-AL dapat ditemukan pada penjelasan Pasal 9 huruf b UU TNI sebagai berikut:

"Yang dimaksud dengan menegakkan hukum dan menjaga keamanan adalah segala bentuk kegiatan yang berhubungan dengan penegakan hukum di laut sesuai dengan kewenangan TNI AL (constabulary function) yang berlaku secara universal dan sesuai dengan ketentuan perundangundangan yang berlaku untuk mengatasi ancaman tindakan kekerasan, ancaman navigasi, serta pelanggaran hukum di wilayah laut yurisdiksi nasional. Menegakkan hukum yang dilaksanakan oleh TNI $\mathrm{AL}$ di laut, terbatas dalam lingkup pengejaran, penangkapan, penyelidikan, dan penyidikan perkara yang selanjutnya diserahkan kepada Kejaksaan, TNI AL tidak menyelenggarakan pengadilan."

Dari penjelasan Pasal 9 dapat disimpulkan bahwa kewenangan TNIAL sebagai penyidik di laut sudah jelas dan kewenangan ini tidak dimiliki oleh Bakamla. Sehingga jika Presiden Joko Widodo mengatakan bahwa institusi penegak hukum di laut lainnya akan dikembalikan, maka untuk TNI-AL dikembalikan kemana? Malah sejatinya tugas penegakan hukum oleh TNI-AL merupakan tugas dan fungsi utama TNIAL sebagai salah satu alat pertahanan Negara Kesatuan Republik Indonesia di laut (Ikhsanudin, 2017).

Institusi kedua yang menyebut dirinya sebagai 'coast guard' adalah KPLP, yang mana secara harfiah KPLP jika diartikan ke dalam Bahasa inggris maka KPLP malah mempunyai nama 'sea and coast guard' bukan hanya 'coast guard' saja. Dengan demikian, perlu dibahas tentang tugas, fungsi serta kewenangan KPLP. Setelah melalui sejarah panjang, KPLP merupakan bagian dari Kementrian Perhubungan, khususnya Direktorat Jenderal Perhubungan Laut. Bagian Keempat Peraturan Presiden Nomor 40 Tahun 2015 Pasal 12 menyebutkan bahawa "Direktorat Jenderal Perhubungan Laut mempunyai tugas menyelenggarakan perumusan dan pelaksanaan kebijakan di bidang pelayaran." Pasal 13 selanjutnya menyebutkan fungsi Direktorat Perhubungan Laut meliputi: (i) perumusan kebijakan di bidang penyelenggaraan angkutan di perairan, kepelabuhanan, sarana dan prasarana pelayaran, perlindungan lingkungan maritim, serta peningkatan keselamatan dan keamanan pelayaran; (ii) pelaksanaan kebijakan di bidang penyelenggaraan angkutan di perairan, kepelabuhanan, sarana dan prasarana pelayaran, perlindungan lingkungan maritim, serta peningkatan keselamatan dan keamanan pelayaran; (iii) penyusunan norma, standar, prosedur, dan kriteria di bidang penyelenggaraan angkutan di perairan, kepelabuhanan, sarana dan prasarana pelayaran, perlindungan lingkungan maritim, serta peningkatan keselamatan dan keamanan pelayaran; (iv) pelaksanaan pemberian bimbingan teknis dan supervisi di bidang penyelenggaraan angkutan di perairan, kepelabuhanan, sarana dan prasarana pelayaran, perlindungan lingkungan maritim, serta peningkatan keselamatan dan keamanan pelayaran; (v) pelaksanaan evaluasi dan pelaporan di bidang penyelenggaraan angkutan di perairan, kepelabuhanan, sarana dan prasarana pelayaran, perlindungan lingkungan maritim, serta peningkatan keselamatan dan keamanan pelayaran; (vi) pelaksanaan administrasi Direktorat Jenderal Perhubungan Laut; dan (vii) pelaksanaan fungsi lain yang diberikan oleh Menteri. Peraturan Presiden Nomor 40 Tahun 2015 tentang 
Kementrian Perhubungan ini mengatur juga bahwa Dirjen Perhubungan Laut bertugas menangani semua aktivitas dan segala hal yang bersifat administratif dari International Maritime Organization (IMO) atau institusi internasional lainnya yang bergerak di bidang pelayaran dan perkapalan (Pasal 44 Peraturan Presiden Nomor 40 Tahun 2015 Tentang Kementrian Perhubungan, Lembaran Negara Republik Indonesia Tahun 2015 Nomor 75, 2015).

Selanjutnya Peraturan Menteri Perhubungan Nomor 122 Tahun 2018 tentang Organisasi dan Tata Kerja Kementrian Perhubungan Pasal 264 menyebutkan bahwa Direktorat Perhubungan Laut terdiri atas: 1) Sekretaris Direktorat Jenderal; 2) Direktorat Lalu Lintas dan Angkutan Laut; 3) Direktorat Kepelabuhan; 4) Direktorat Perkapalan dan Kepelautan; 5) Direktorat Kenavigasion; dan 6) Direktorat Kesatuan Penjagaan Laut dan Pantai.

Pasal 388 Peraturan Menteri Perhubungan tersebut menguraikan tugas Direktorat Kesatuan Penjaaan Laut dan Pantai yang meliputi:

“...tugas melaksanakan perumusan dan pelaksanaan kebijakan, penyusunan norma, standar, prosedur dan kriteria, pemberian bimbingan teknis dan supervisi, serta evaluasi dan pelaporan di bidang patroli dan pengamanan, penegakan hukum dan advokasi, tertib pelayaran di laut dan pantai, penanggulangan musibah dan pekerjaan bawah air, sarana dan prasarana."

Sementara itu Pasal 389 mengatur tentang fungsi Direktorat Kesatuan Penjaga Laut dan Pantai yang meliputi: (i) penyiapan perumusan kebijakan di bidang patroli dan pengamanan, penegakan hukum dan advokasi, tertib pelayaran di laut dan pantai, penanggulangan musibah dan pekerjaan bawah air, serta sarana prasarana; (ii) penyiapan pelaksanaan kebijakan di bidang patroli dan pengamanan, penegakan hukum dan advokasi, tertib pelayaran di laut dan pantai, penanggulangan musibah dan pekerjaan bawah air, serta sarana prasarana; (iii) penyiapan penyusunan, norma, standar, prosedur, dan kriteria di bidang patroli dan pengamanan, penegakan hukum dan advokasi, tertib pelayaran di laut dan pantai, penanggulangan musibah dan pekerjaan bawah air, serta sarana prasarana; (iv) penyiapan pelaksanaan pemberian bimbingan teknis dan supervisi di bidang patroli dan pengamanan, penegakan hukum dan advokasi, tertib pelayaran di laut dan pantai, penanggulangan musibah dan pekerjaan bawah air, serta sarana prasarana; (v) penyiapan evaluasi dan pelaporan di bidang patroli dan pengamanan, penegakan hukum dan advokasi, tertib pelayaran di laut dan pantai, penanggulangan musibah dan pekerjaan bawah air, serta sarana prasarana; dan (vi) pelaksanaan urusan tata usaha, perencanaan, keuangan, kepegawaian, organisasi dan ketatalaksanaan, pengelolaan teknologi informasi dan komunikasi, serta rumah tangga Direktorat. Pasal 390 kemudian menyebutkan bahwa Direktorat Kesatuan Penjaga Laut dan Pantai terdiri dari beberapa subdirektorat yang meliputi (i) subdirektorat Patroli dan Pengamanan; (ii) subdirektorat Penegakan hukum; (iii) subdirektorat Tertib Berlayar; (iv) subdirektorat Penanggulangan Musibah dan Pekerjaan Bawah Air; (v) subdirektorat Sarana dan Prasarana serta (vi) subbagian Tata Usaha. Untuk subdirektorat penegakan hukum, dengan jelas terdapat fungsi penyidik yang merupakan salah satu fungsi dari subdirektorat penegakan hukum. Sebagaimana diatur dalam Pasal 396 Peraturan Menteri Perhubungan Nomor 122 Tahun 2018 tentang Organisasi dan 
Tata Kerja Kementrian Perhubungan, menyebutkan fungsi subdirektorat penegakan hukum meliputi: (i) penyiapan bahan perumusan kebijakan di bidang penegakan hukum, penyidikan dan intelijen, pelaporan kualifikasi teknis Penyidik Pegawai Negeri Sipil dan Intelijen, pelaksanaan penegakan hukum desiminasi pengawasan keselamatan transportasi laut, serta pengendalian dan pengawasan pangkalan; (ii) penyiapan bahan pelaksanaan kebijakan di bidang penegakan hukum, penyidikan dan intelijen, pelaporan kualifikasi teknis Penyidik Pegawai Negeri Sipil dan Intelijen, pelaksanaan penegakan hukum desiminasi pengawasan keselamatan transportasi laut, serta pengendalian dan pengawasan pangkalan; (iii) penyiapan bahan penyusunan norma, standar, prosedur dan kriteria di bidang penegakan hukum, penyidikan dan intelijen, pelaporan kualifikasi teknis Penyidik Pegawai Negeri Sipil dan Intelijen, pelaksanaan penegakan hukum desiminasi pengawasan keselamatan transportasi laut, serta pengendalian dan pengawasan pangkalan; (iv) penyiapan bahan pelaksanaan bimbingan teknis dan supervisi di bidang penegakan hukum, penyidikan dan intelijen, pelaporan kualifikasi teknis Penyidik Pegawai Negeri Sipil dan Intelijen, pelaksanaan penegakan hukum desiminasi pengawasan keselamatan transportasi laut, serta pengendalian dan pengawasan pangkalan; dan (v) penyiapan bahan evaluasi dan pelaporan di bidang penegakan hukum, penyidikan dan intelijen, pelaporan kualifikasi teknis Penyidik Pegawai Negeri Sipil dan Intelijen, pelaksanaan penegakan hukum desiminasi pengawasan keselamatan transportasi laut, serta pengendalian dan pengawasan pangkalan (Pasal 396 Peraturan Menteri Perhubungan Nomor 122 Tahun 2018 tentang Organisasi dan
Tata Kerja Kementerian Perhubungan, 2018).

Dari uraian di atas, bisa diketahui bahwa dari sekian banyak institusi yang mempunyai kewenangan sebagai penegak hukum di laut setidaknya terdapat empat institusi yang benarbenar saling tumpang tindih dari segi pengaturan kewenangannya, yaitu Bakamla, TNI-AL, KPLP serta institusi yang belum dibentuk yang merupakan amanah dari Pasal 276 UU Pelayaran. Dengan demikian, jika diterapkan konsep omnibus law pada aspek penegakan hukum di laut, dari empat instutisi tersebut, jika kita kembalikan pada pernyataan Presiden Joko Widodo bahwa selain Bakamla akan dikembalikan ke institusi masingmasing, lalu mau dikembalikan kemana TNI-AL? padahal TNI-AL merupakan salah satu unsur pertahanan dan keamanan negara yang mempunyai matra laut sehingga memang sejatinya institusi ini merupakan penegak hukum di laut yang juga mempunyai fungsi penyidikan di laut.

\section{Pengaturan Penegakan Hukum di Laut ke Depan}

Penerapan konsep omnibus law, sebagaimana diuraikan sebelumnya merupakan upaya pemerintah untuk menyatukan beberapa undang-undang yang tumpang tindih. Hal ini sesuai dengan spirit omnibus law sebagai regulasi atau UndangUndang yang mencakup berbagai isu atau topik. Saat ini penerapan konsep omnibus law dapat ditemukan pada Rancangan Undang-Undang Cipta Kerja (yang saat ini sudah disahkan menjadi Undang-Undang). Pada Pasal 20 RUU Cipta Kerja, memang menyebutkan perubahan pada UU Kelautan, hanya saja perubahan yang dilakukan hanya yang berkaitan dengan pengelolaan wilayah laut serta perizinannya. Hal ini sesuai dengan awal mula penerapan konsep ini di Indonesia, yaitu untuk perbaikan perekonomian. Sehingga omnibus law di Indonesia hanya diterapkan pada 3 aspek 
yang meliputi perpajakan, cipta lapangan kerja serta Usaha Mikro Kecil dan Menengah (UMKM), bukan pada segala aspek perundang-undangan. Akan tetapi dengan tujuan menghilangkan tumpang tindih pengaturan, saat ini konsep omnibus law menyasar ke segala aspek yang dianggap mempunyai pengaturan yang tumpang tindih. Tak terkecuali pada penegakan hukum di laut, karena terdapat tumpang tindih kewenangan sebagaimana yang diuraikan di atas, maka konsep omnibus law pun sudah dipikirkan untuk diterapkan pada aspek penegakan hukum di laut. Meskipun tidak ada yang salah dengan hal ini, penerapan omnibus law di bidang penegakan hukum di laut harus mempertimbangkan zona-zona maritim yang ada serta hak negara lain di masing-masing zona maritim tersebut, sebagaimana diatur dalam KHL 1982. Dalam rapat koordinasi khusus tingkat Menteri tentang penanganan keamanan laut, telah diuraikan draft penerapan konsep omnibus law di bidang penegakan hukum di laut (Indonesia, 2020). Pada prinsipnya, yang akan disatukan adalah UU Kelautan dan UU Pelayaran.

Dari draft penggabungan Bakamla dan KPLP menjadi sea and coast guard dapat dilihat bahwa perubahan dan/ penggabungan yang direkomendasikan ada pada penyatuan tugas dan fungsi serta yang paling penting adalah adanya perluasan daerah operasi dari sea and coast guard yang merupakan penyatuan dari unsur Bakamla dan KPLP. Dalam rekomendasi penyatuannya, baik sea and coast guard maupun Bakamla direkomendasikan untuk bisa mempunyai daerah operasi yang juga meliputi wilayah yurisdiksi. Hal ini kurang tepat mengingat sesuai dengan Pasal 9 UU TNI bahwa yang berwenang melakukan penegakan hukum di laut diwilayah yurisdiksi Indonesia adalah TNI-AL. Sedangkan UU Wilayah negara Pasal 1 ayat (3) menyebutkan bahwa wilayah yurisdiski adalah wilayah di luar wilayah negara yang meliputi ZEE, Zona tambahan dan landas kontinen. Perluasan daerah operasi yang direkomendasikan tidak bisa dilaksanakan mengingat pada wilayah yurisdiski terdapat hak negara lain yang lebih besar daripada hak negara lain di laut teritorial.

Meskipun upaya penggabungan tersebut menyarankan bahwa Bakamla dan KPLP digabung menjadi sea and coast guard dengan berbagai fungsi dan tugas yang disebut single agency multi task dan memperluas daerah operasinya, akan tetapi hal ini kurang tepat. Hal ini dikarenakan terdapat perbedaan kewenangan negara pantai dan/ kepulauan pada satu zona maritim yang satu dengan zona maritim yang lain. Ditambah lagi adanya hak dan kewajiban negara lain di wilayah laut, bahkan pada wilayah laut yang merupakan wilayah kedaulatan negara pantai dan/ kepulauan. Dengan demikian, tentunya Bakamla tidak mempunyai kewenangan sebagai penegak hukum tunggal di laut. Eksistensi TNI-AL juga perlu diperhatikan karena TNI-AL merupakan salah satu unsur pengaman negara yang tidak hanya berperan dalam penegakan hukum di laut kaitannya dengan combatan, akan tetapi TNI-AL juga mempunyai peran non-combatan sebagaimana diuraikan dalam Trisila TNIAL. Hal ini sesuai dengan UU TNI. Bisa saja institusi penegak hukum selain TNI-AL dijadikan satu menjadi Bakamla dan mungkin nama Bakamla bisa berubah menjadi Indonesian Coast Guard tetapi bukan sea and coast guard. Hal ini dikarenakan nomenklatur 'sea' akan mengaburkan makna dikarenakan akan mengundang pertanyaan laut yang mana? Indonesian Coast Guard yang demikian ini kemudian dapat melakukan penegakan hukum hanya di perairan Indonesia, sedangkan TNI-AL tetap mempunyai fungsi penegakan hukum di wilayah yurisdiksi Indonesia serta fungsi penegakan kedaulatan di wilayah perairan Indonesia.

\section{Simpulan dan Saran}

Dari uraian di atas, dapat disimpulkan bahwa penerapan konsep omnibus law bukan merupakan satu-satunya jalan untuk menyelesaikan tumpang tindih kewenangan pada pengaturan penegak hukum di laut. 
Penerapan konsep omnibus law bahkan kurang tepat mengingat terdapat perbedaan kewenangan negara pantai dan/ kepulauan pada satu zona maritim yang satu dengan zona maritim yang lain. Hal ini juga dikarenakan adanya hak dan kewajiban negara lain di wilayah laut, bahkan pada wilayah laut yang merupakan wilayah kedaulatan negara pantai dan/ kepulauan.

Selanjutnya, jikalau akan menyatukan Bakamla dengan institusi penegak hukum yang lain menjadi single agency multi tasking menjadi coast guard tidak masalah. Hal ini asalkan nomenklaturnya bukan lagi sea and coast guard akan tetapi hanya coast guard. Ditambah lagi TNI-AL tetap menjalankan fungsinya sebagai penegak hukum di laut sebagaimana diatur dalam UU TNI serta melakukan peran combatan dan non-combatan sesuai dengan Trisila TNIAL.

\section{DAFTAR PUSTAKA}

Agoes, E. R. (1991). Konvensi Hukum Laut 1982: Masalah Pengaturan Hak Lintas Kapal Asing.

Aziz, N. A., L, R. T. S., \& Hardiwinoto, S. (2016). Kewenangan Badan Keamanan Laut (BAKAMLA) dalam Pelaksanaan Pengamanan di Wilayah Perairan Indonesia. Diponegoro Law Journal, 5(4), 11.

BeritaSatu. https://www.youtube.com/watch?v=0BS6hEOhc8. In Youtube.

Booth, K. (1985). Law, Force and diplomacy at Sea, Winchester, Allen \& Uwin.

Churchill, R. R., \& Lowe, A. V. (1999). Law of the Sea.

Dupuy, R., \& Vignes, D. (1991). A Handbook of the New Law of the Sea. Dordrecht: Martinus Nijhoff Publishers.

Emmers, R. (2010). Geopolitic and Maritime Territorial Disputes in East Asia. New York: Routledge.
Feldt, L., Roell, P., \& Thiele, R. D. (2013). Maritime Security - Perspectives for a Comprehensive Approach. ISPSW Strategy Series, n.22.

Garner, B. A. (2009). Black's Law Dictionary.

Harahap, M. (2017). Penegakan Hukum di Laut dalam Zona Ekonomi Eksklusif. Jurnal Hukum Dan Pembangunan, 14(1).

Ikhsanudin, A. H. (2017). Sinergi BAKAMLA dengan TNI AL Guna Penanggulangan Tindak Pidana di Laut dalam Rangka Penegakan Hukum. Jurnal Prodi Strategi Pertahanan Laut, $3(3)$.

Indonesia, K. P. R. (2020). Rapat Koordinasi Khusus Tingkat Menteri: Pembahasan Penanganan Keamanan Laut.

Kadar, A. (2015). Pengelolaan Kemaritiman Menuju Indonesia sebagai Poros Maritim Dunia. Jurnal Keamanan Nasional, 1(3).

Mahmud, F. (2017). Peranan Perhubungan Dalam Penegakan Hukum di Laut Khususnya dalam Zona Ekonomi Eksklusip. Jurnal Hukum Dan Pembangunan, 14(5).

Muchjiddin, A. M. (1993). Status Hukum Perairan Kepulauan Indonesia dan Hak Lintas Kapal Asing.

Nursal, H. I. (2020). Kewenangan Bakamla RI dalam Penegakan Hukum di Laut. Dipresentasikan Pada Forum Group Discussion Kewenangan Bakamla Dan Sea and Coast Guard Dalam Penegakan Hukum Di Perairan Indonesia, 25 Juli 2020.

Omnibus Law Kelautan, Bakamla Penegak Hukum Tunggal di Laut. (2020). CNN Indonesia.

Peraturan Menteri Perhubungan Nomor 122 Tahun 2018 tentang Organisasi dan 
Tata Kerja Kementrian Perhubungan. , (2018).

Peraturan Presiden Nomor 40 Tahun 2015 tentang Kementrian Perhubungan, Lembaran Negara Republik Indonesia Tahun 2015 Nomor 75. , (2015).

Pranoto, H., \& Amrulla, O. (2015). Security Strategy at Indonesia Sea Lanes. Jurnal Pertahanan, 1(2), 93-108.

Purvis, C. (2011). Coastal State Jurisdiction Under UNCLOS: The Shen Neng 1 Grounding on The Great Barrier Reef. The Yale Journal of International Law, $36(207)$.

Puspitawati, D. (2018). Hukum Laut Internasional. Prenada Media.

Ramadhan, C. (2020). Kewenangan Kelembagaan Dalam Penegakan Hukum di Perairan Indonesia.

Ruolngul, J. R. (n.d.). Security, Politics and Regional Integration. Retrieved from http://www.articlesbase.com/politicsarticles/security-politics-and-regionalintegration-asean-mercosur-and-sadc836206.html

Suwardi. (2017). Penegakan Hukum di Zona Ekonomi Eksklusif. Jurnal Hukum Dan
Pembangunan, 15(1).

TNI AL. (2014). Keamanan Laut. Di Presentasian Pada Kuliah Umum Di Fakultas Hukum Universitas Brawijaya, 19 Maret 2014.

Undang-Undang Nomor 32 Tahun 2004 tentang Tentara Nasional Indonesia, Lembaran Negara Republik Indonesia Tahun 2004 Monor 127, Tambahan Lembaran Negara Republik Indonesia Nomor 4439. , (2004).

Undang-Undang Nomor 32 Tahun 2014 tentang Kelautan Lembaran Negara Republik Indonesia Tahun 2014 Nomor 294, Tambahan Lembaran Negara Republik Indonesia Nomor 5603. , (2014).

Undang-Undang Nomor 34 Tahun 2004 tentang Tentara Nasional Indonesia Lembaran Negara Republik Indonesia Tahun 2004 Nomor 127. , (2004).

Undang Undang Nomor 17 Tahun 2008 tentang Pelayaran, Lembaran Negara Republik Indonesia Tahun 2008 Nomor 64, Tambahan Lembaran Negara Republik Indonesia Nomor 5603. , (2008). 